\title{
Metropolitan Area Growth: A Test of Export Base Concepts
}

\author{
by CLIFTON B. LUTTRELL and CHARLES M. GRAY
}

\begin{abstract}
Economists have developed two different views of urban growth. One view holds that growth stems from increased demand for a city's output for export. This leads to expansion of employment in the exporting sector and to a multiple expansion of other employment. The other view is that migration to a city, which expands the supply of labor, leads to increased employment and economic growth.
\end{abstract}

Although the two views are not mutually exclusive, most studies of urban growth lean toward the former approach. This article concentrates on the record of nine Central Mississippi Valley metropolitan areas during the $1960^{\prime} \mathrm{s}$, and finds that emphasis on the export base view to the exclusion of other factors leaves much of the growth process unexplained.

LL Standard Metropolitan Statistical Areas ${ }^{1}$ in the Central Mississippi Valley made gains during the $1960^{\circ} \mathrm{s}$, as indicated by commonly used measures of economic activity. Employment in the nine metropolitan areas combined rose at the annual rate of 2.9 per cent from 1960 to 1968 . Population rose at a 1.4 per cent rate from 1960 to 1968 , and per capita personal income rose at a 3.1 per cent rate in the nine years ending in 1968. Employment and per capita personal income gains exceeded the national rates of 2.6 and 2.9 per cent, respectively, while population growth was at a somewhat lower rate than the national average of 1.6 per cent.

Although each of the regional SMSAs made gains in most measures of economic activity, the rates of growth among the areas differed widely. Employment increases ranged from a 2.3 per cent an-

\footnotetext{
IStandard Metropolitan Statistical Areas (SMSAs) consist primarily of one or more whole counties containing at least one central city of 50,000 population or more. SMSAs studied in this article are as defined by the Bureau of the Budget in April 1967 and are the same geographic areas for the period studied.

This study includes the Cental Mississippi Valley (CMV), composed of the whole states of Arkansas, Kentucky, Missism sippi, Missouri, and Tennessee, and also includes all other SMSAs in the Eighth Federal Reserve District (see map on facing page).
}

nual rate in St. Louis to 4.6 per cent in Texarkana. Population gains ranged from two-tenths of one per cent in Evansville to 2.2 per cent in Little Rock. Per capita income corrected for price changes rose at only a 2 per cent annual rate in Fort Smith, compared with 6.4 per cent in Texarkana. These wide variations of movement in growth indicators among regional SMSAs and between the regional and national SMSA average raise questions as to what constitutes a meaningful concept for measuring SMSA progress, and why such variations occur.

\section{Meaning of Growth}

Economic analysts generally recognize two broad categories of growth: volume or aggregate growth, and growth in economic well-being. Aggregate gains, such as population increases, higher gross output, and increases in total demand for goods and services, may have no relationship to individual welfare. There may be no direct relation, for example, between population growth and efficient operations of the competitive market or output of goods and services per person. India, Pakistan, and Egypt have had a high rate of population growth, but these nations are not noted for high rates of progress in well-being. Some elements of the local economy, such as employers, re- 


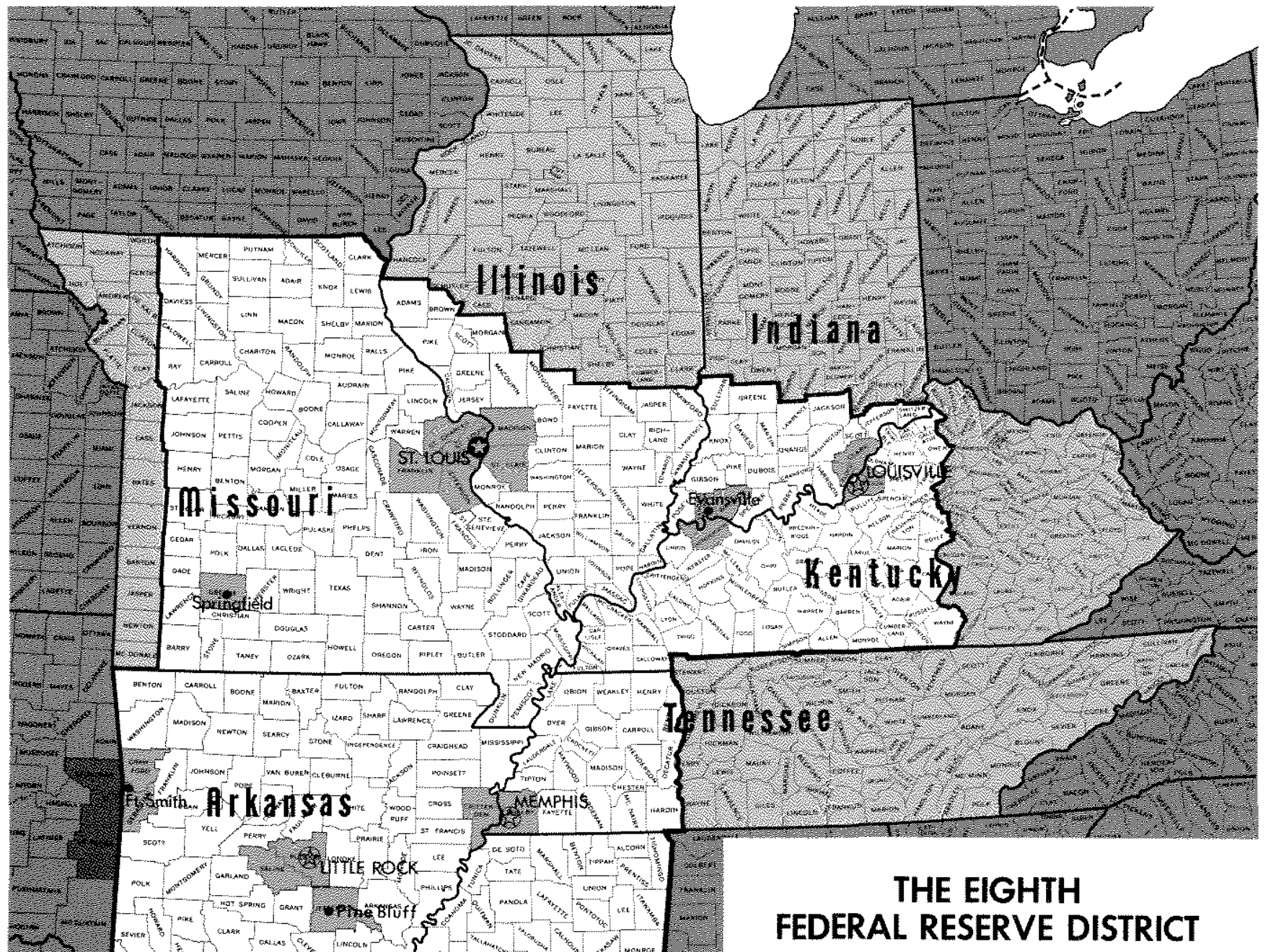

Showing Adjoining Counties and States LEGEND

- District Boundary

State Boundaries

County Boundaries

Head Office of the Federal

- Reserve Bank of St. Louis

Branch Office of the Federal

क Reserve Bank of St. Louis

Standard Metropolitan Statistical Area 
tailers, owners of idle resources, and new immigrants may benefit from population gains. Other groups, however, who may have already paid for such capital items as schools, parks, public buildings, and churches, may be called upon to share their resources with the newcomers or to shoulder additional expenses as a result of rapid population growth. If new residents are unskilled, they may make disproportionately large demands upon the public sector, while their tax contributions are small. ${ }^{2}$

In contrast to volume growth, a rise in material well-being, as indicated by real per capita income gains, is applauded by most students of economic development. Growth in well-being may be indicated by rising real per capita income and rising per capita consumption of goods and services. These factors point to greater efficiency in the production and marketing of goods and services in an area.

A relatively high rate of employment growth may also indicate rising well-being. Assuming average labor force growth, if jobs are created faster in a particular area than in other areas, labor is bid away from current occupations elsewhere, or new employees are bid into the labor force. Other things being equal, the fact that employers in an area can profit by hiring such labor indicates a higher rate of gain in productivity here than elsewhere.

Although gains in real per capita income and relatively high rates of employment growth in an area indicate improvement in well-being, these measures provide no explanations of growth. Such analyses tell little about how progress starts and accelerates. For example, how does an area or region develop entrepreneurs and reorient itself from a static economy to one built around capital growth, labor specialization, flexible use of resources, and wider commercial exchange of goods and services?

\section{Export Base Concepts}

The export base approach to urban and regional growth analysis focuses attention primarily on the demand for goods and services from outside the local economy. ${ }^{3}$ Local industries which have a large out-

The ultimate desirability of immigration thus depends on whether those who stand to gatin as a result oan in some way compensate those who stand to lose. This criterion is treated extensively in the literature of "welfare economics" and further discussion of the problem can be found in George $H$. Borts and Jerome L. Stein, Economic Growth in a Free Market (New York: Columbia University Press, 1964), pp. $190-193$.

3 Another concept of urban growth is founded on the observation that a city grows through a series of separable stages. side market are more responsive to changes in national demand than those with output limited to the local market, and are collectively termed the "export base." The group of industries which develops to service the export base and the local populace, and which consists largely of wholesaling and retailing establishments along with services and certain types of light industry, is termed the "nonbasic" sector. A rough line of dependence can be constru ed, leading from outside demand, to the base, and then to the domestic sector. If an assumption is made that the nonbasic sector maintains a constant relationship to the basic sector over time, then it can be shown that total employment growth is a multiple of basic employment growth. ${ }^{4}$

As a refinement of the export base theory, Stanislaw Czamanski devised a method of separating the total employment of an SMSA into three sectors. ${ }^{.}$His clas" sifications have been used in this article. Industries located in an SMSA primarily because of locational advantages in a national market are called geographically-oriented industries. Industries in this sector include: coal mining, petroleum and gas extraction, primary metals industries, motor vehicles and equipment, machinery, meat products, and Federal Government operations. Employment in this sector is designated $\mathrm{E}_{\mathrm{g}}$ in this article.

A second class of industries includes those which locate in an SMSA to provide inputs to the geographically-oriented industries, to utilize outputs of that sector, or to take advantage of economies resulting from the prior location of geographically-oriented in-

The products of various industrial sectors are assumed to have different incone elasticities of demand so that a secular in crease in income leads to a shift in sectoral prominence. Although demand plays a role, the chief emphasis is on the ability of the locality to supply factors of production. Further discussion of this approach can be found in Wilbur $R$. Thompson, A Preface to Urban Economics (Baltimore: The Johns Hopkins Press, 1969), especially pp. 15 ff., and Harvey S. Perloff et al, Regions, Resources, and Economic Growth (New York: Cambridge University Press, 1960), pp. 58-60.

tThe idea of such a multiplicative effect within a region received impetus from the "investment multiplier" hypothesized by J. M. Keynes in The General Theory of Employment, Interest, and Money (New York: Harcourt, Brace \& Co., 1936), especially p. 115. Perhaps the most complete statement of this theory can be found in Ralph $W$. Pfouts, ed. The Techniques of Urban Economic Analysis (West Trenton, N. J.: Chandler-Davis Publishing Co., 1960), which includes an extensive treatment of export base analysis. A recent statement of the importance of exports is in Jane Jacobs, "Strategies for Helping Cities," American Economic Review, September I969, pp. 652-656.

"Stanislaw Czamanski, "A Model of Urban Growth," Papers, Regional Science Association, (1964), pp. 177-200; and "A Method of Forecasting Metropolitan Crowth by Means of Distributed Lags Analysis," Journal of Regional Soience, (1965), pp. 35449. 
dustries in the area. This complementary sector displays a strong dependence upon the geographically-oriented sector and is also responsive to national demand. Employment in this sector is designated $\mathrm{E}_{\mathrm{c}}$. Typical industries include knitting mills, other textile mills, petroleum and coal products, and rubber products.

Finally, the urban-oriented sector constitutes that group of industries which arises to service the urban area. Employment in this sector is designated $\mathrm{E}_{\mathrm{u}}{ }^{6}$ Included are such industries as construction, bakery products, printing and publishing, wholesale and retail trade, banking, finance, insurance, laundry and cleaning, hotels, recreation, education, welfare and religious organizations, and local government.

A central purpose of this sectoral division is to provide a means for using the export base theory to estimate future growth of an urban area. The following is an application of the theory with Czamanski's sectoral division adapted to each metropolitan area in the CMV states.

\section{St. Louis}

The St. Louis area, with a 1968 population in excess of 2.3 million, is the largest metropolitan center in the CMV (Table I). Like other large, older metropolitan areas in the nation, St. Lotis has had a relatively low employment growth rate (Table II). The rate of 2.3 per cent in the period 1960-68 was the smallest among the CMV metropolitan areas and was below the average for major labor market areas in the United States, which grew at a 2.6 per cent rate. Likewise, St. Louis had a relatively low growth rate in geographically-oriented employment $\left(E_{z}\right)$, which accounts for more than one-fifth the area total (Table III). Only Fort Smith, with a rate of 0.4 per cent, was below St. Louis. Fed-

6The sectors in Czamanski's analysis are not uniformly defined for every size SMSA. For example, a producer of furniture may locate in a large SMSA because of related industries there which provide economies of production. In this case the producer would be in the complementary sector. In a very small SMSA, however, a similar producer may supply a large geographical area without benefit of closely related industries. In this latter case it would be classified in the geographically-oriented industries. Allowances of this sort have been made wherever possible in this article.

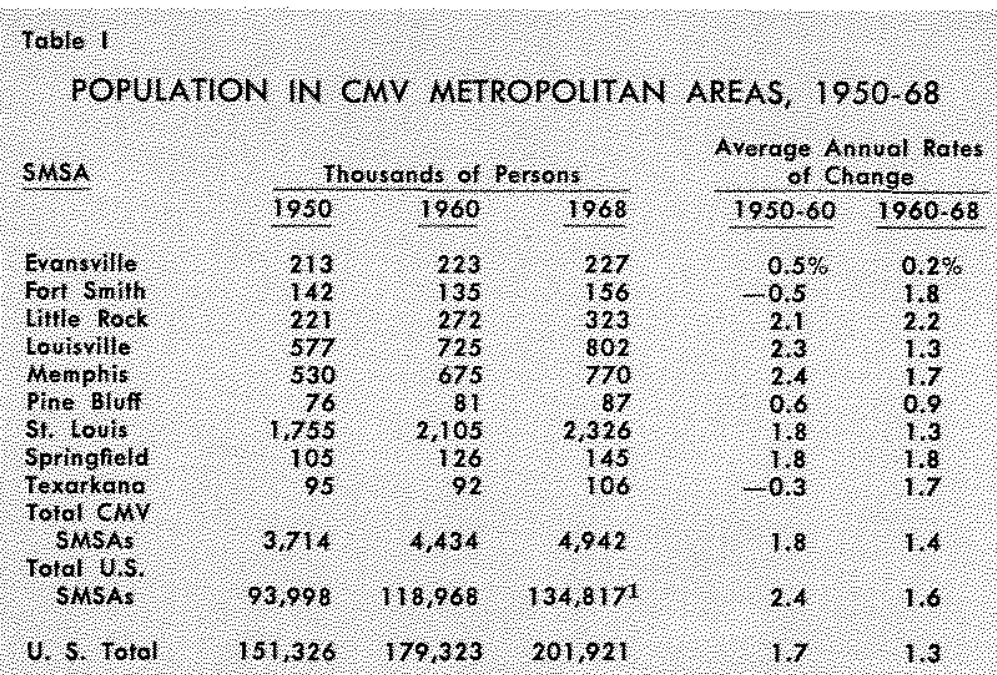

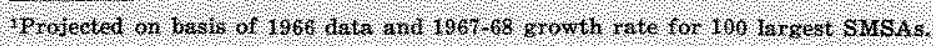

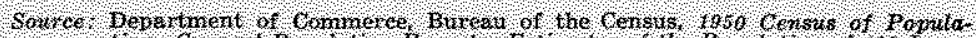

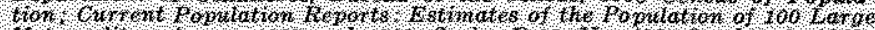

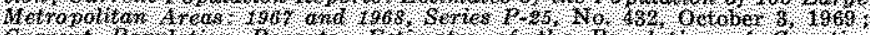

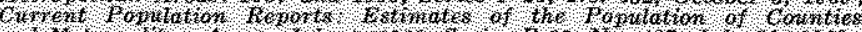

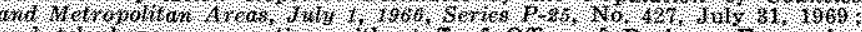

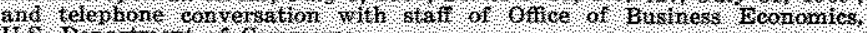
1s beparmert 0 tommeres eral government, aircraft and parts, and ordnance were among the major growth sectors within the $E_{\mathrm{g}}$ classification. Employment declines occurred in meat packing, leather, and some other nondefense industries in this classification.

Complementary employment $\left(E_{\mathrm{e}}\right)$, which accounted for less than 4 per cent of the area total, actu-

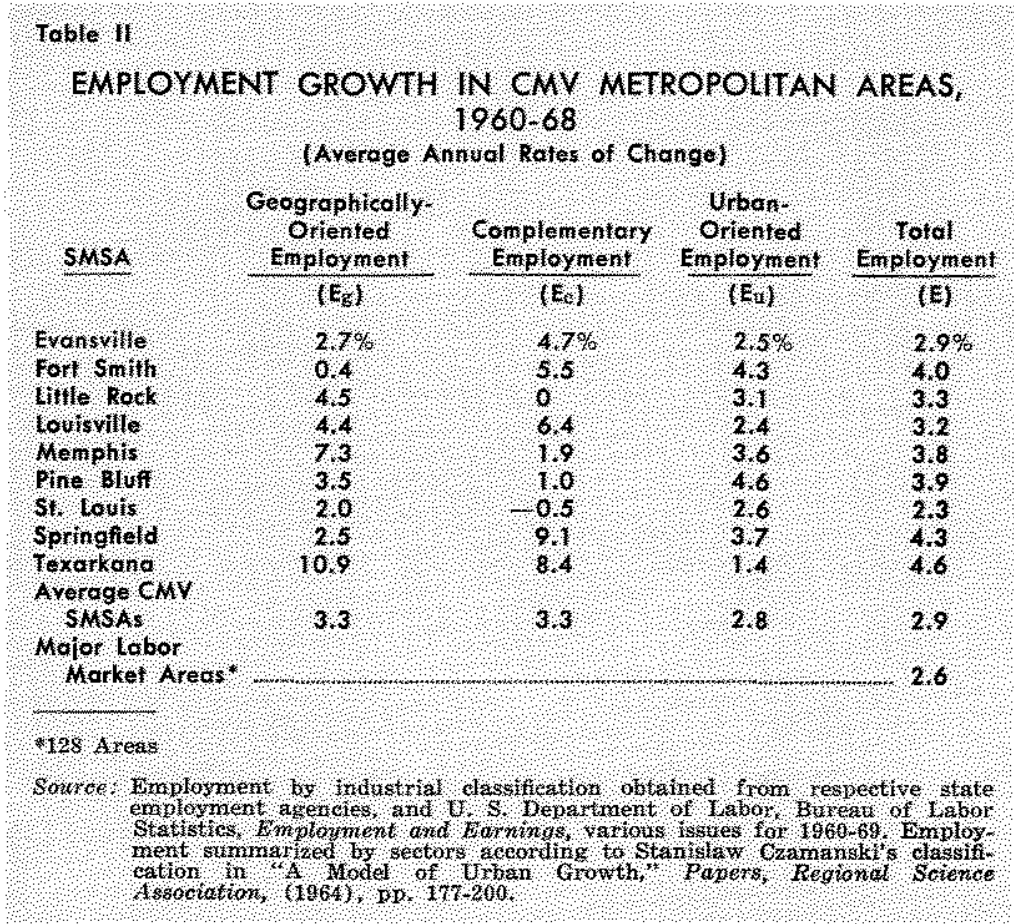




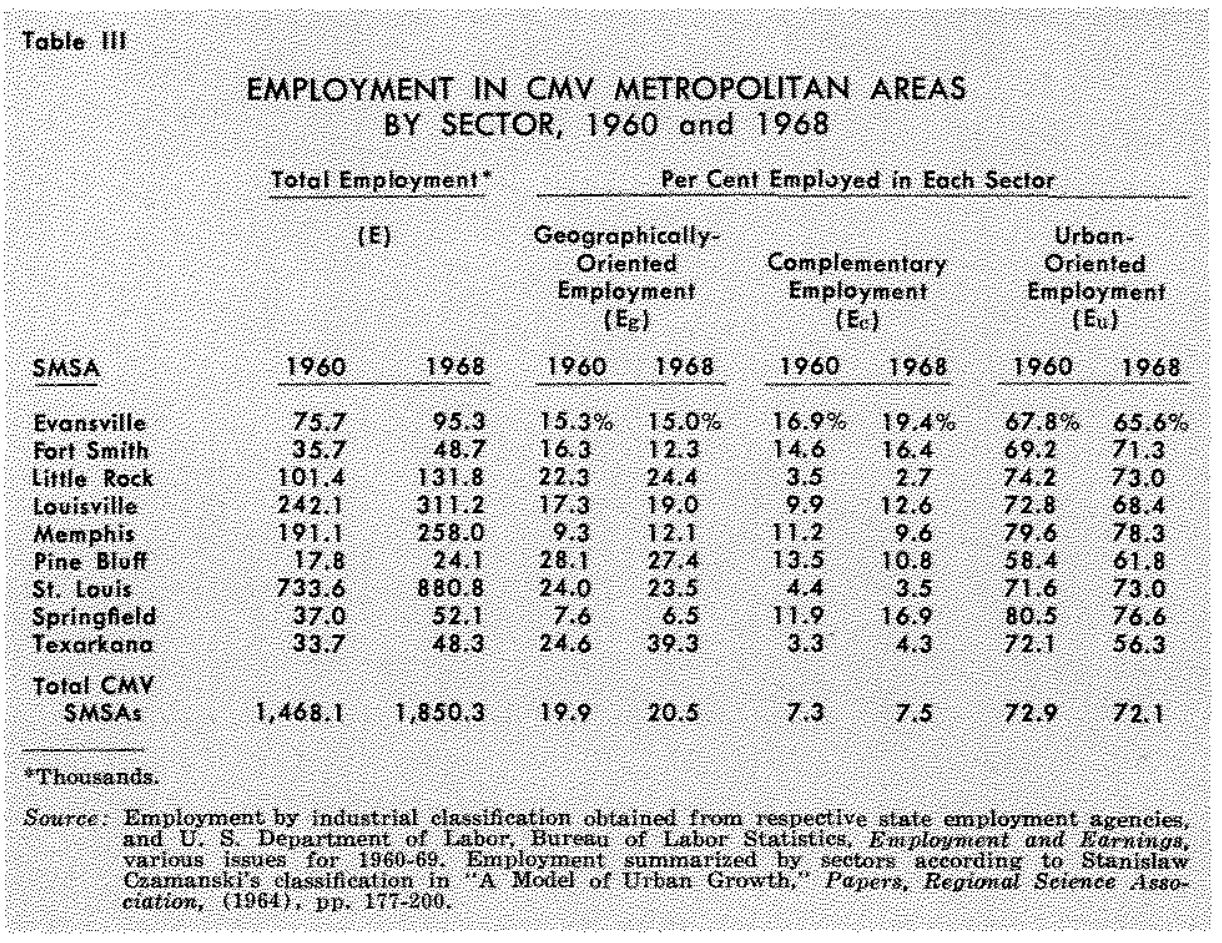

higher growth rate of urbanoriented industries. ${ }^{7}$ Employment in these urban-oriented industries, almost three-fourths of total employment, rose at a 2,6 per cent annual rate. Many service-type industries benefit from the high rate of spending by employees in the exporting sector.

Population in St. Louis grew at a 1.3 per cent rate during 1960-68, slightly below the rate for the CMV metropolitan area total and below the 1.6 per cent rate for all United States SMSAs (Table I). Population growth in $S t$. Louis, however, was about the same as in other larger centers. Such centers have in recent years grown at slightly lower rates than medium-sized areas. For

ally declined in the 1960-1968 period. Part of this decline in $\mathrm{E}_{\mathrm{c}}$ can probably be accounted for by the major shifts in the type of geographically-oriented industries located in the area. Those which declined were more likely to attract complementary industries than those which gained in employment. For example, nondefense industries, such as meat packing and leather, can be expected to attract some closely allied industries. On the other hand, defense industries may not be subject to the same degree of competition as nondefense industries, and may not be forced to be quite so cost conscious. Hence they may not attract such complementary industries as suppliers of component parts to the area.

The large growth in Federal Government and defense employment may have had some retarding influence on the more market-oriented industries in St. Louis. One reason may be the fact that the more rapidly growing geographically-oriented defense industries in St. Louis generally pay above-average wage rates for the area. These locally high wages may reduce the competitive ability of other exporting industries in this labor market. Such nondefense exporting industries sell part of their output in regional, national, or international markets and must compete with products from other labor market areas where wages may be determined more competitively. Conversely, high wage rates in St. Louis geographically-oriented industries may have contributed to the somewhat example, SMSAs with a population of two million or more grew 1.4 per cent per year during the period 1960-66, while those with populations of two hundred thousand to two million grew 2 per cent per year. ${ }^{8}$

According to export base theories, the lower-thanaverage rate of population growth in St. Louis is consistent with a lower rate of job creation. Causation is viewed, however, as running from job creation to population growth. This view excludes the possibility of reverse causation. The results of a study of 135 cities by Richard Muth indicated that migration and employment growth both affect and are affected by each other. ${ }^{9}$ Thus the low rate of job creation may not have been a predominant cause of the slow population growth in St. Louis. Immigration may have resulted in the low rate of job creation, or other factors such as inefficiency of production could have caused both the low rate of job creation and of population growth.

Per capita personal income growth in St. Louis was consistent with the below-average rate of job and population growth for the area (Table IV). Such income rose over $\$ 600$ per person during the period 1959-68, approximating the average dollar increase

iSee Table V, equation 1 for the impact of $\mathbf{E}_{g}$ on total employment and other relationships relative to "export base" assumptions for each of the CMV metropolitan areas.

8 U.S. Department of Commerce, Bureau of the Census, Series P.25, No. 427, July 31, 1969.

9See Richard F. Muth, "Migration: Chicken or Egg?" (Working paper, Washington University, 1969). 


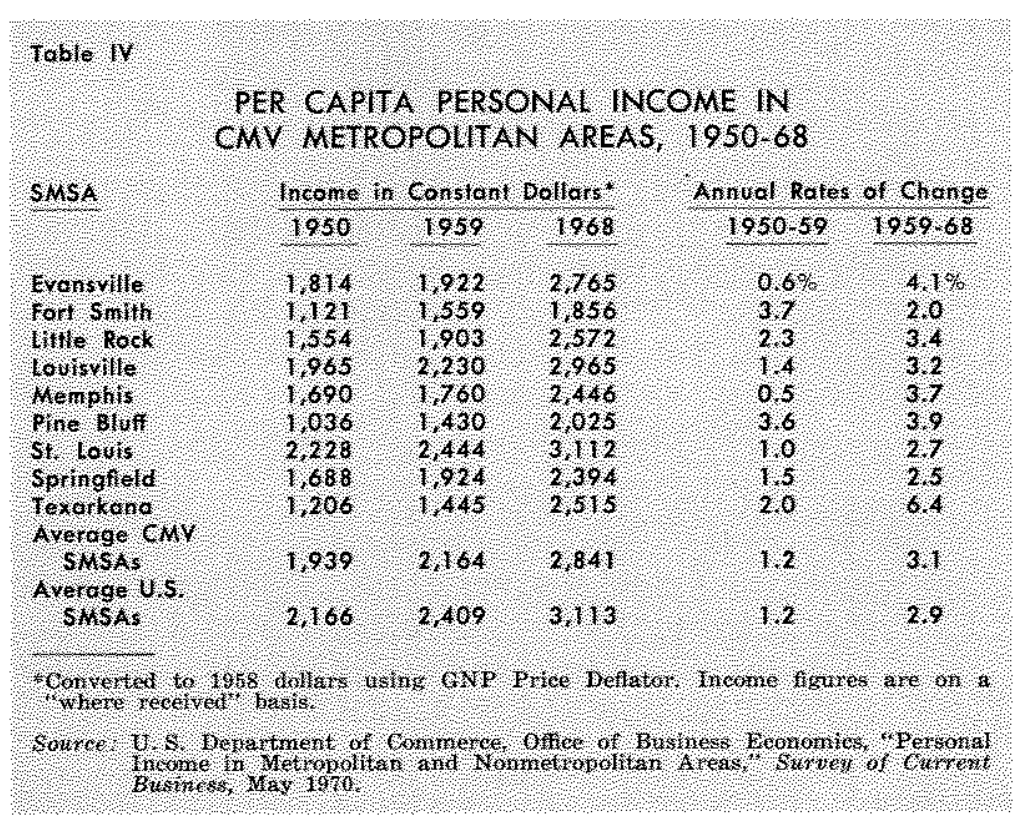

ployment totaling 11.5 thousand, almost three-fourths of the $\mathrm{E}_{\mathrm{g}}$ total in 1966 , declined to 11.1 thousand in 1969. Employment in mining declined from 1.9 to 1.6 thousand. A slight increase in Federal Goveinment employment was insufficient to offset these declines.

Complementary employment, amounting to 18.5 thousand in 1968 or almost one-fifth the total, consists largely of employment in fumiture and fixtures, rubber and plastics, fabricated metals, and other miscellaneous manufacturing industries. Employment in the rubber and plastics industry is relatively new for the area, beginning in early 1966 with 2.5 thousand workers, and expanding to 3.1 thousand in 1968. Some expansion occurred during the 1960-68 period in furntture and fixtures, fabricated metals and mis-

for all metropolitan areas in the CMV. With a rate of increase of 2.7 per cent per year, however, the gain here was at a lower rate than for most CMV metropolitan areas and somewhat below the weighted average national SMSA rate of gain. Despite this below-average rate of gain, personal income per capita in St. Louis of $\$ 3,112$ in 1968 was well above the average for all other SMSAs in the CMV states, and about equal to the national average for all metropolitan areas.

\section{Evansville}

Evansville, a medium-sized SMSA in the CMV states, has made gains in recent years equal to the CMV average and slightly greater than the national SMSA average in employment, below average for both in population, and above average in personal income (Tables I, II, IV).

Geographically-oriented employment rose at the rate of 2.7 per cent. Such employment rose sharply from 1961 to 1964 , at a somewhat slower rate from 1964 to 1966, and declined on balance from 1966 to 1968. With moderate time lags, $\mathrm{E}_{c}$ and $\mathrm{E}_{u}$ employment generally followed the $\mathrm{E}_{\mathrm{g}}$ trend. Employment in these sectors accelerated after 1962 and tended to level out after 1967.

The decline in $\mathrm{E}_{g}$ after 1966 was the result of reductions in machinery manufacturing industries and mining. Employment in this sector of 15.3 thousand in 1966 accounted for almost one-sixth of total employment in the SMSA. Machinery manufacturing emcellaneous types of $\mathrm{E}_{\mathrm{c}}$ employment. The period 1964-67 was one of especially rapid employment growth in these industries.

Population in Evansville was virtually unchanged from 1960 to 1968 and grew only 0.5 per cent per year in the prior decade (Table I). In the 1950's the city lost two industries which were a major portion of all geographically-oriented employment. As a result, the unemployment rate at the turn of the 1960 decade was relatively high, averaging more than 7 per cent of the labor force. In comparison, unemployment rates ranged from 4.1 to 6.8 per cent of the labor force in the four larger metropolitan areas in the CMV. Furthermore, unemployment in Evansville remained somewhat above average for other regional SMSAs during most of the 1960 decade. This relatively high unemployment rate was probably a factor in the low rate of population growth in Evansville.

Per capita income growth in Evansville has been at a relatively high rate during recent years, averaging 4.1 per cent from 1959 to 1968 (Table IV). This was the highest rate of gain of all the CMV metropolitan areas except Texarkana. In the previous decade, however, per capita income in Evansville grew at the relatively low rate of 0.6 per cent. Much of this disparity can be traced to the major loss of industries in the 1950 's and the resulting high unemployment rates at the end of the decade. With the proportion of the population employed down, per capita incomes were relatively low at the turn of the decade. Conversely, with a higher proportion of the population employed in 1968 (unemployment rate of 3.3 per cent), real per capita income was up sharply. 
Despite the low rate of gain in the prior decade, the per capita personal income of $\$ 2,765$ in 1968 was relatively high for regional SMSAs. It was exceeded in the CMV only by St. Louis and Louisville, but it was still about 10 per cent below the United States SMSA average.

\section{Font Sminh, Ancansas - O klahome}

Both employment and population in Fort Smith increased from 1960 to 1968 at higher rates than the regional or national SMSA averages (Tables I and II). Total employment rose 4 per cent per year compared with an average of 2.9 per cent for all regional SMSAs and 2.6 per cent for 128 major national labor market areas. Population rose at a 1.8 per cent rate, higher than most other regional SMSAs and well above the rate of 1.6 per cent for all U. S. SMSAs.

The highest rate of employment gains was in the complementary sector, which currently constitutes about 16 per cent of the total (Table III). Employment in this sector grew 5.5 per cent per year, most of which is attributed to expansion in furniture manufacturing. Employment in this industry totaled 5,200 in 1968 or more than 60 per cent of the sector total.

Geographically-oriented employment grew only 0.4 per cent per year. Employment in this sector was almost stable from 1963 to 1968, but by 1969 employment in metals industries had risen by about 800 workers, increasing total employment in the sector by about 10 per cent. Metals industries currently account for about 60 per cent of $\mathrm{E}_{\mathrm{g}}$ in the area; Federal Government, 25 per cent; and mining and stone, clay, and glass industries, the remaining 15 per cent.

Urban-oriented employment in Fort Smith increased at the relatively high rate of 4.3 per cent from 1960 to 1968 . This sector accounts for 71 per cent of all jobs in the area, about the average per cent for the region.

Employment growth trends in Fort Smith reflect the closing of a large military base in the area. The dismantling of this base and the replacement of military by civilian personnel apparently altered labor demand sufficiently to have a sizeable impact on employment in trade, transportation, and construction.

Population growth in Fort Smith exceeded most other CMV metropolitan areas during the years 1960-68, despite the dismantling of the military installation. The sharp increase after 1960 probably indicates migration from nearby counties to the Fort
Smith SMSA. Population in the SMSA, which comprises four counties, declined during the $1950^{\prime} \mathrm{s}$ as a result of rural migration to other parts of the nation.

A relatively low per capita income increase per year occurred in Fort Smith from 1959 to 1968 along with high rates of employment and population growth (Tables I, II, and IV). Average per capita personal income rose only 2 per cent per year, below average for SMSAs in the region and below the 2.9 per cent average rate for all SMSAs in the nation.

\section{Witzle Rock}

Employment in Little Rock grew 3.3 per cent per year during the period 1960-68. This was slightly above average for both the regional SMSAs and major national labor markets (Table II).

Geographically-oriented employment, which now accounts for one-fourth the total for the area, grew at the relatively high rate of 4.5 per cent. This growth represents primarily the expansion of one firm engaged in making fabricated steel and aluminum products. Complementary employment, which was already low at the beginning of the decade, declined further as a percentage of total employment during the period (Table III).

Urban-oriented employment, which accounted for 73 per cent of the total, grew at a 3.1 per cent rate. Employment in this sector is heavily weighted by wholesale and retail trade, construction, financial agencies, local government, and services.

Population in Little Rock grew 2.2 per cent per year from 1960 to 1968 , the highest rate of all regional SMSAs and well above the national SMSA average (Table I). Population growth was also above average for the region in the prior decade. This higher-than-average rate of population growth in recent years may reflect the fact that a high rate of industrialization and migration from the farms occurred later in Arkansas than in most other states of the CMV. These trends were having an important impact on regional SMSA population growth after they ceased to have a major impact on SMSA growth in other regions.

Per capita personal income in Little Rock grew at above-average rates for regional and national SMSAs in both the recent and prior decades (Table IV). Such income in Little Rock grew at a 2.3 per cent annual rate in the 1950's and a 3.4 per cent rate from 1959 to 1968 . In 1950 per capita personal income in Little Rock was only 80 per cent of the regional 
SMSA average, but in 1968 had risen to 91 per cent. This rapid increase of income growth, coupled with relatively high population and employment growth rates, indicates a substantial rise in production efficiency and a sharp increase in demand for labor in the Little Rock SMSA.

\section{Lounsulile}

Total employment in the Louisville SMSA grew at a rate of 3.2 per cent from 1960 to 1968 , exceeding the average for SMSAs in the region and for large national labor markets (Table II). Employment gains of 4.4 per cent per year in the geographically-oriented sector were also relatively high, exceeding all other SMSAs in the region except Little Rock, Memphis, and Texarkana. This sector, which constitutes almost one-fifth of total employment in the area, is heavily weighted by machinery manufacturing employees. Such employees, which account for about one-half the $\mathrm{E}_{\mathrm{g}}$ total, rose from 20 to 27 thousand during the six-year period 1963.69 .

Although employment in all three sectors rose, the increase of 6.4 per cent per year in complementary employment ( 13 per cent of the total) was especially rapid. Gains in this sector after 1965 were heavily weighted by increases in the manufacture of electric appliances. These increases are attributed largely to the decision of one firm to establish a major manufacturing center in Louisville. Small $\mathrm{E}_{\mathrm{e}}$ increases occurred in lumber and wood products, chemicals, and other nondurables, which were about offset by declines in employment in fixtures, apparel, and related products.

Employment in urban-oriented occupations, which account for 68 per cent of the total, rose somewhat less than average for SMSAs in the region and substantially less than the other sectors in Louisville. Modest growth occurred, however, in all types of $\mathrm{E}_{4}$ occupations, including services, trade, finance, transportation, local government, fabricated metals, food and kindred products, and publishing.

Population in Louisville, the second largest SMSA in the region, grew at a below-average rate for regional and national SMSAs in the period 1960 to 1968, which was inconsistent with the high rate of employment growth. Louisville, however, had a relatively high rate of population growth for the region during the prior decade, averaging 2.3 per cent per year, the second highest rate among the regional SMSAs and almost equal to the national SMSA average of 2.4 per cent (Table 1).
Per capita personal income in the Louisville area is the second highest of all SMSAs in the CMV states, averaging $\$ 2,965$ (Table IV). Such income was slightly above the Evansville average, but was 5 per cent below the St. Louis and national SMSA average. Per capita income in Louisville rose 3.2 per cent per year from 1959 to 1968 , slightly above the regional SMSA growth rate and exceeding the national SMSA average. Such income growth in the prior decade exceeded both the regional and national SMSA average.

\section{Memphis}

Employment in the Memphis SMSA grew at an annual rate of 3.8 per cent, greater than both regional and national SMSA average rates in the 1960 's (Table II). Growth occurred in all three employment sectors, with especially sharp gains pereentage-wise in geographically-oriented employment. Growth in this sector stemmed from a relatively small base and reflects primarily the establishment of a new electric appliance plant employing about six thousand people, almost doubling $\mathrm{E}_{\mathrm{g}}$ in the area.

In contrast to rapid $\mathrm{E}_{\mathrm{g}}$ gains, growth in the complementary sector was at the relatively low rate of 1.9 per cent. This sector is likewise relatively small, accounting for less than 10 per cent of total employment in the area.

Employment in Memphis is primarily urban-oriented with $\mathrm{E}_{a}$ constituting 78 per cent of the total (Table III). Growth of 3.6 per cent in this service area was well above average for the region. The city developed historically around wholesale and retail trade designed to serve both the local urban area and the smaller communities over a large trade area. Despite the recent sharp upturn of $\mathrm{E}_{\mathrm{g}}$, the service sector declined only slightly relative to total employment. Wholesale and retail trade still provide about one-fourth of the area's jobs, while other urban type services, such as local government, finance, transportation, construction, food processing, fabricated metals, and printing and publishing, provide the remaining 55 per cent.

Population growth in Memphis was well above the regional SMSA average and slightly higher than the national rate from 1960 to 1968 . Population growth here of 1.7 per cent per year was exceeded only by Fort Smith, Little Rock, and Springfield, and was equal to Texarkana in the region (Table I). During the prior decade this growth in Memphis exceeded all other SMSAs in the region. The high rate of popu- 
lation growth here was consistent with a relatively high rate of employment growth.

Per capita personal income in Memphis increased sharply in recent years along with jobs and population. Such income rose 3.7 per cent per year from 1959 to 1968 after a relatively low rate of gain in the prior decade. In the recent period per capita personal income growth in Memphis was exceeded only by Evansville, Pine Bluff, and Texarkana of the regional SMSAs, and was well above regional and national SMSA averages (Table IV).

Despite the recent income gains, per capita income in the area remains relatively low, averaging $\$ 2,446$ in 1968 , or 86 per cent of the regional SMSA average, and 79 per cent of the national SMSA average.

\section{Pine Bluff, Arkansas}

Pine Bluff, the smallest SMSA in the region, had a relatively high rate of employment growth from 1960 to 1968 . The 3.9 per cent growth rate here was well above CMV and national SMSA averages and was exceeded in the CMV states only by Fort Smith, Springfield, and Texarkana (Table II).

Geographically-oriented employment, which accounts for more than one-fouth the area total, grew 3.5 per cent per year, less than total employment growth but slightly above the average $\mathrm{E}_{\mathrm{g}}$ gain for the region. The large $\mathrm{E}_{\mathrm{g}}$ sector in Pine Bluff and its high growth rate reflect primarily a govemment-operated ordnance plant which had sizeable employment gains during the period. Excluding the ordnance plant, $\mathbf{E}_{\mathrm{g}}$ here accounts for less than 15 per cent of total employment, and growth was quite nominal, rising from 2.9 to 3.4 thousand, only 1.8 per cent per year.

The complementary sector, which accounts for about 11 per cent of total employment, grew only at the rate of 1 per cent and declined relative to total employment during the period. Urban-oriented employment, accounting for about three-fifths the area total, rose at a 4.6 per cent rate, the highest $E_{u}$ growth rate of any SMSA in the region and well above the growth rate of other employment sectors in Pine Bluff.

Per capita personal income in Pine Bluff rose 3.9 per cent per year, an above-average rate for both CMV and national SMSAs (Table IV). This high rate of per capita income gain, coupled with high employment growth, indicates rising labor productivity in the Pine Bluff area. Population in Pine Bluff grew
0.9 per cent per year in the period $1960-68$, a rate well below both the regional and national SMSA averages.

\section{Springfield, Missoun}

Total employment in Springfield increased at a rapid rate relative to SMSAs in both the CMV and the nation from 1960 to 1968 . The 4.3 per cent rate of employment growth was exceeded only by Texarkana among the CMV metropolitan areas and was more than 50 per cent greater than the average CMV and national SMSA rates (Table II).

Geographically-oriented employment changed little on balance during the decade. It declined slightly from 1960 to 1965 , increased sharply for the next two years, was unchanged from 1967 to 1968 , and declined sharply from 1968 to 1969 . The closing of a large machinery manufacturing plant in the area was a major factor in the sharp 1968-69 decline. Relative to the total, geographically-oriented employment declined from 7.6 to 6.5 per cent during the $1960-68$ period (Table III).

In contrast to little $\mathrm{E}_{\mathrm{g}}$ growth, complementary employment rose throughout most of the decade with especially rapid gains after 1964. Such employment more than doubled, rising from 4.4 to 9.6 thousand, and relative to total employment, increasing from 11.9 to 16.9 per cent. These gains are attributed to sharp increases in a wide variety of manufacturers of both durable and nondurable goods. New plants or expansions resulted in larger employment in the manufacture of industrial ventilators, radios, plastics, boxes, cement, and shoes.

Urban-oriented employment, which accounts for more than three-fourths the total, grew 3.7 per cent per year, an above-average rate of growth for all regional SMSAs.

The Springfield population has in recent years grown at a high rate consistent with the employment gains. Population increased 1.8 per cent per year from 1960 to 1968 , somewhat faster than either the CMV or national SMSA average. This rate was equaled by Fort Smith but was exceeded in the CMV states only by Little Rock (Table I).

In contrast to the rapid employment and population gains, per capita personal income in the Spring field area grew at a relatively low rate during the years 1959 to 1968 . Average real income rose only 2.5 per cent per year, compared with a 3.1 per cent rate for the regional SMSA total. The rapid increase 
in employment, coupled with only nominal gains in per capita income in the area, reflects a relatively elastic labor supply in the Springfield area.

\section{Texarkana, Arkansas - Texas}

Total employment in Texarkana grew at the relatively high rate of 4.6 per cent per year from 1960 to 1968 , the highest rate of any SMSA in the CMV states and well above the 2.6 per cent average rate for major national labor markets. Most of the area's employment gains are attributed to a sharp increase in the geographically-oriented sector.

Geographically-oriented employment, which consists largely of workers in ordnance manufacturing, rose sharply with the expansion of Viet Nam military operations in 1965. Such employment now constitutes almost two-fifths of total employment in the area, up from less than one-fourth the total in $1960 . \mathrm{E}_{\mathrm{g}}$ here is the largest per cent of total employment of all SMSAs in the region.

Employment in complenentary industries likewise increased at a high rate, but this sector still constitutes less than 5 per cent of the area total. Urbanoriented employment was apparently little affected by sharp increases in the $E_{5}$ and $E_{c}$ sectors. Such employment grew only 1.4 per cent per year, well below the average rate for $\mathrm{E}_{u}$ in all metropolitan areas in the CMV states. The number of employees in transportation and utilities and the self-employed remained about unchanged diring the period, while small increases occurred in construction, finance, services, and state and local government.

Population in Texarkana grew at a 1.7 per cent rate from 1960 to 1968 , somewhat faster than the SMSA average in the region and slightly faster than the national SMSA average. Population in the area declined somewhat during the prior decade, reflecting migration from the rural portions of the two counties which currently comprise the SMSA.

Per capita personal income in Texarkana has grown at the highest rate of all SMSAs in the region and more than double the regional and national SMSA averages. Most of this sharp increase is attributed to the major increase in ordnance employment and the relatively high wage rates prevailing in this industry.

\section{Statistical Analysis of Area Growth Patterns}

As indicated in the tables and charts, wide variations occurred in employment growth patterns among the metropolitan areas in the CMV. The sharp gains of geographically-oriented employment $\left(\mathrm{E}_{\bar{g}}\right)$ in Memphis in 1965, for example, were not followed by rising growth rates of complementary $\left(\mathrm{E}_{\mathrm{c}}\right)$ and urbanoriented $\left(E_{n}\right)$ employment. $E_{g}$ grew faster in Little Rock than other employment categories throughout most of the period. In contrast, $\mathrm{E}_{\mathrm{u}}$ growth led other sectors in St. Louis, and $E_{c}$ grew fastest in Springfield. These diverse patterns cast doubt on the validity of applying any single explanation of employment growth uniformly among urban areas. This section investigates these growth trends more rigorously using statistical analysis.

If growth of $\mathrm{E}_{\mathrm{g}}$ and $\mathrm{E}_{\mathrm{e}}$ generate additional employment expansion within a labor market area, as postulated by export base theorists, then from the following equations one would expect the indicated results, where each coefficient is significantly different from zero:

$$
\begin{aligned}
& \text { (1) } \Delta \mathrm{E}=\mathrm{a}+\mathrm{b} \Delta \mathrm{E}_{\mathrm{g}} \\
& \mathrm{b}>1 \\
& \text { (2) } \Delta \mathrm{E}=\mathrm{a}+\mathrm{b} \Delta\left(\mathrm{E}_{\mathrm{g}}+\mathrm{E}_{\mathrm{g}}\right) \\
& \mathrm{b}>1 \\
& \text { (3) } \Delta \mathrm{E}_{\mathrm{u}}=\mathrm{a}+\mathrm{b} \Delta\left(\mathrm{E}_{\mathrm{c}}+\mathrm{E}_{\mathrm{g}}\right) \\
& \mathrm{b}>0 \\
& \text { (4) } \Delta \mathrm{E}_{\mathrm{c}}=\mathrm{a}+\mathrm{b} \Delta \mathrm{E}_{\mathrm{g}}
\end{aligned}
$$

On the other hand, if $\mathrm{E}_{g}$ or $\mathrm{E}_{\text {c }}$ growth "crowd out," or replace, expansion in another sector, contrary to the postulates of the export base approach, the following are the expected results:

$$
\begin{aligned}
& \text { (1') } \Delta \mathrm{E}=\mathrm{a}+\mathrm{b} \Delta \mathrm{E}_{\mathrm{g}} \\
& \text { (2') } \underset{b \leq 1}{\Delta E} a+b \Delta\left(E_{1}+E_{g}\right) \\
& \text { (3) } \underset{b \leq 0}{\Delta E_{a}}=a+b \Delta\left(E_{e}+E_{g}\right)
\end{aligned}
$$

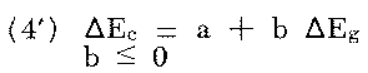

Table $V$ should be interpreted in light of these expectations. The equations in this article have incorporated the approximate form of (1)-(4) above, utilizing lagged values of the independent variables in each case.

The time series regressions of employment growth by sectors in individual cities further confirm the relatively small impact of geographicallymoriented employment growth on employment in other sectors. First differences of quarterly data indicate that geographically-oriented employment had some initial impact on total employment in most CMV metropolitan areas (Table V). In equation ( 1 ) the coefficient for the current quarter was significant at the 5 per cent 
rable V

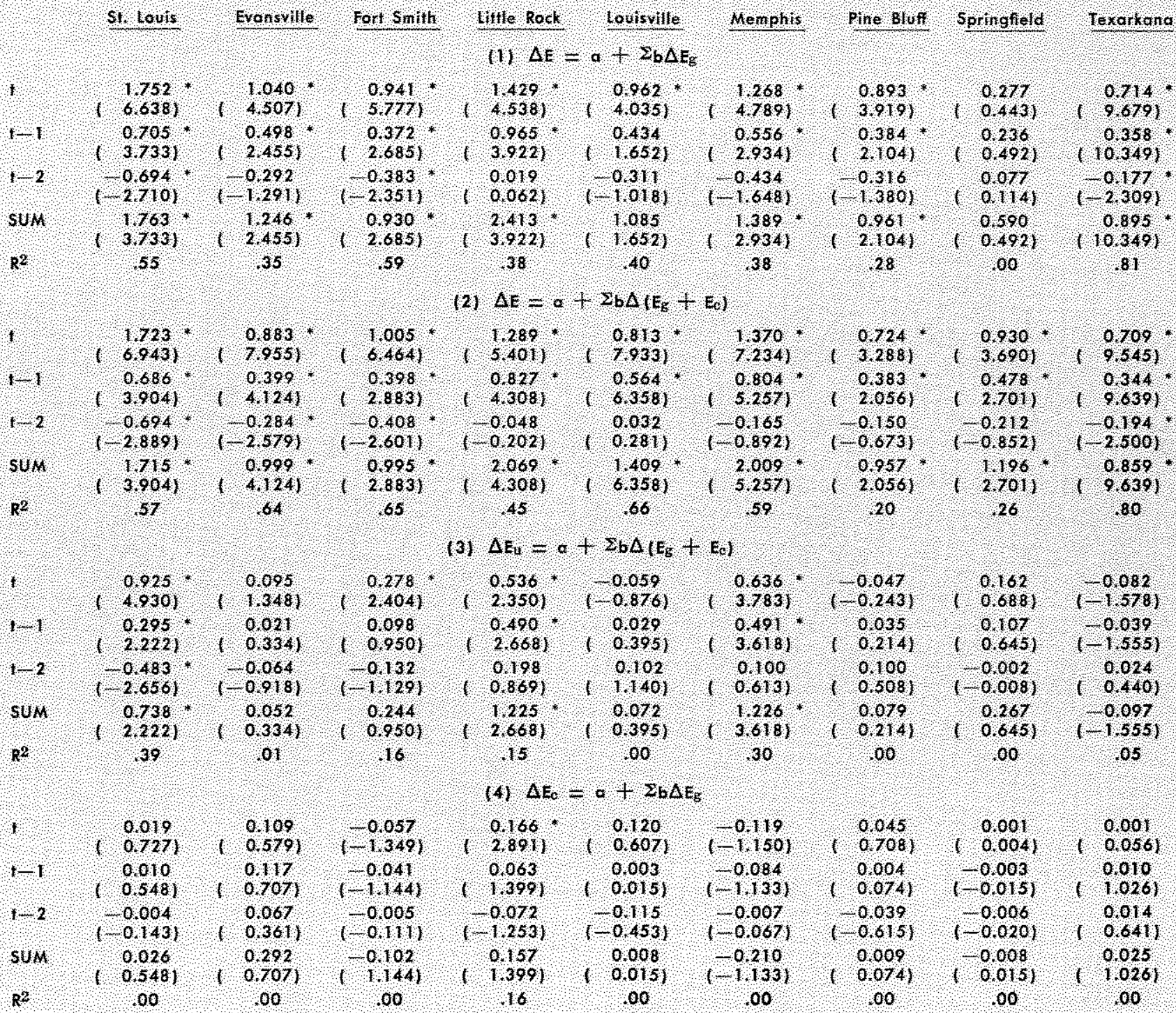

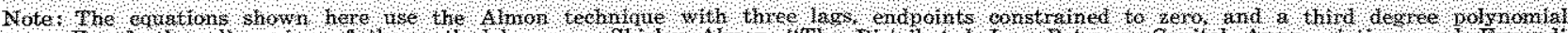

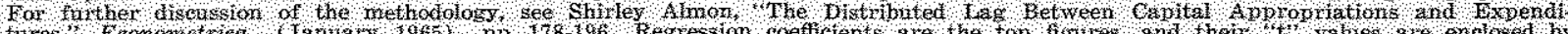

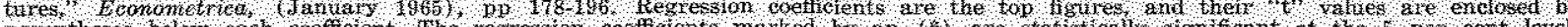
1 a t

level for eight of the nine SMSAs, and the sums of the coefficients for three quarters were significant in seven of the nine SMSAs.

The impact multiplier was positive for each city and averaged slightly greater than unity in the current period. The lagged multipliers, however, changed signs after the second quarter for most cities and tended to reduce the total multiplier. The sums of the multipliers for those SMSAs with significant coefficients ranged from a high of 2.4 in Little Rock to 0.9 in Texarkana and Fort Smith, and averaged 1.4.
Three of the seven SMSAs with significant coefficients indicated some crowding out; that is, an increase in $E_{\mathrm{g}}$ led to less employment in other sectors.

The combined relationship of $\mathrm{E}_{\mathrm{s}}$ and $\mathrm{E}_{\mathrm{s}}$ to total employment, as indicated in equation (2), is significant for every SMSA in the region. The results vary greatly, however, with total multipliers exceeding 2 in both Little Rock and Memphis. Substantial crowding out is indicated in Texarkana, and coefficients were slightly less than unity in three other SMSAs. 
Equation (3) results are inconclusive with regard to the induced expansion of urbanworiented employment. The summed coefficients are positive for the most part, but they show significance only for St. Louis, Little Rock, and Memphis. Crowding out is indicated in Texarkana although the coefficient is not significant.

Equation (4) investigates the hypothesis that geographically-oriented industries attract complementary activities. No significant correlations were found between $E_{\S}$ and $E_{c}$. Almost as many coefficients were negative as were positive in the lagged quarterly data, and sums of the coefficients were negative in three of the SMSAs. In addition to the lag structure included in Table $V$, lags up to three years were tested on this equation as well as the other equations, with essentially unchanged results.

Spearman rank correlation analysis likewise reveals little relationship between the growth rates of the various employment sectors (Table VI). Although causation cannot be determined from this method, failure of correlation results to support a theory indicates that the theory is incomplete at best. Such basic tenets of the export base theory as the impact of $E_{g}$ on $E_{c}, E_{g}$ on total employment, and $E_{g}$ on population are not supported by the Spearman rank correlation coefficients, indicating little relationship between these factors.

This analysis does indicate, however, some important growth relationships. Geographiclly-oriented em-

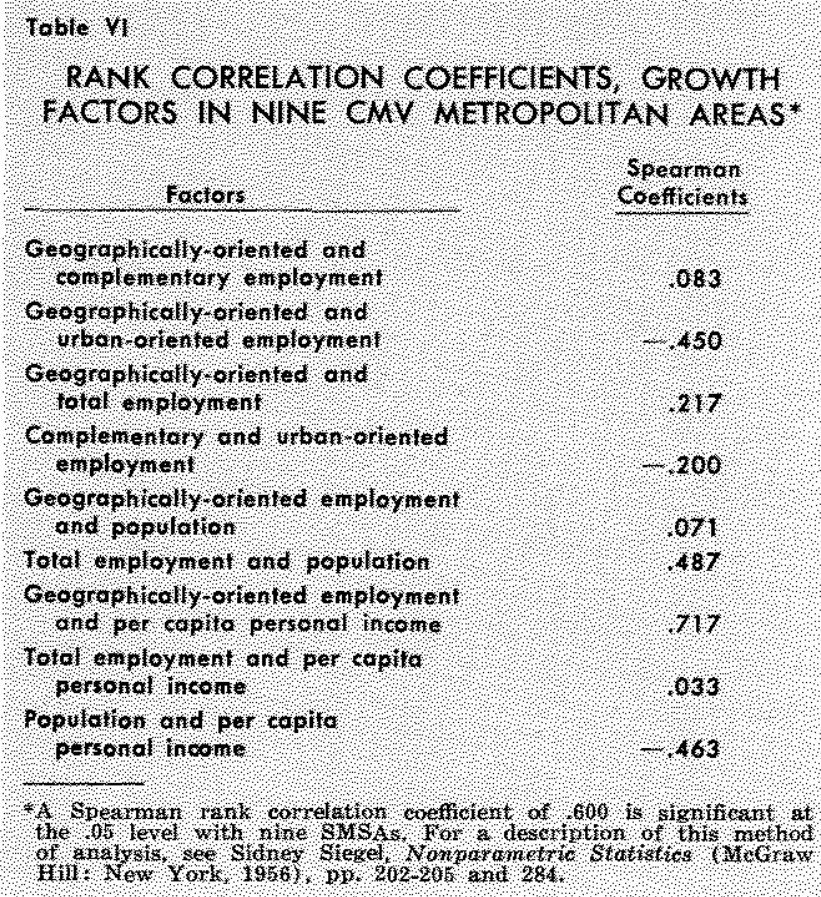

ployment was significantly associated with per capita personal income growth. Furthermore, correlations of three other relations $-E_{\mathrm{g}}$ and $\mathrm{E}_{\mathrm{u}}$, total employment and population, and population and per capita personal income-approach significance, the first and last with negative coefficients and employment and population with a positive one.

\section{Evaluation of Statistical Relationships}

There are a number of possible reasons why export base analysis has not proven more useful for explaining growth in the CMV areas. First, the theory tends to focus primarily on demand for output of exporting industries. Demand for a city's output, however, is derived from two sources, the local economy and the rest of the world. A city's growth in employment, according to the export base thesis, relies primarily on growth of national and intemational demand for export goods. Growth of the export sector may be offset, however, by a decline in resource availability for the urban and complementary sectors. These sectors are influenced by resource demands of the export industries. For example, wholesaling and warehousing facilities which are included in the urban-oriented sector may be moved to lower cost locations as a result of $E_{s}$ demands for labor in an SMSA. Such effects imply that industry classification by sector may not only be unstable over the longer pull, but may also be unstable over relatively short spans as the relative efficiency of production changes in an SMSA.

Second, the export base view tends to ignore supply factors, including the fact that economies and diseconomies of production and input availability have an observable impact on employment and output. If the supply of labor is relatively inelastic with respect to wage rates, a gain in $\mathrm{E}_{\mathrm{g}}$ may tend to crowd out employment elsewhere. On the other hand, if the supply of labor is relatively elastic with respect to wages, a gain in $\mathrm{E}_{\mathrm{g}}$ may induce employment gains in other sectors as has occurred in Little Rock and Memphis. Ultimately, the community which can produce more efficiently will likely grow faster.

Third, there is the question of the use of employment statistics as a measure of the economic base. To the extent that the labormoutput ratio changes at different rates in different industries over time, the linear specification of the equations tested may be inappropriate. Furthermore, it is difficult to determine with precision the proportion of employment engaged in producing goods and services for export. The method used here may lead to some bias in the results. 
Fourth, demand for output by sector may grow at unequal rates. The nonbasic service sector, for instance, is experiencing great secular expansion nationally. ${ }^{10}$ As income increases over time, the population tends to demand more services relative to goods.

Finally, growth in both per capita income and geographically-oriented employment in a given SMSA (excluding military related jobs) may be more related to basic factors, such as capital accumulation and the acquisition of managerial and labor skills, than to increases in national demand for a few products which happen to be currently produced in a given SMSA.

\section{Crowding Out Effects}

The crowding out effects of gains in $\mathrm{E}_{\mathrm{g}}$ on employment in other sectors are not only indicated in statistical analysis of the data, but also on an a priori basis. Export type industries generally pay higher wages than local service type industries. In January 1969, production workers in durable goods manufacturing and ordnance and accessories had average weekly eamings of $\$ 136.70$ and $\$ 139.59$ respectively in the United States. In comparison, average earnings of all nonagricultural production workers were $\$ 110.63$ per week. ${ }^{11}$

A rise in money wages which results from an increase in export demand has effects which both increase and reduce demand for labor in the domestic sector. ${ }^{12}$ The increase in money wages leads to an increase in income per family, higher demand for domestic output, and an increase in derived demand for domestic employment. The rise in money wages relative to the price of domestic output, however, provides incentive for the substitution of other factors for labor in domestic production. Furthermore, a rise in price of domestic output tends to reduce the quantity of such output demanded and thereby the quantity of labor demanded.

\footnotetext{
to According to a recent study, "the Service sector's share of total employment has grown from approximately 40 per cent in 1929 to over 55 per cent in 1967 . Between 1947 and 1965 alone, there was an increase of 13 million jobs in the Service sector compared with an increase of only 4 million in Industry [primarily manufacturing] and a decrease of 3 million in Agriculture." Victor R. Fuchs, The Service Economy, (New York: National Bureau of Econonic Research, $1969)$, p. 2.

wU.S. Department of Labor, Monthly Labot Review, (March 1969), pp. 104 and 105.

12Richard F. Muth, "Differential Growth Among Large U.S. Cities," (Working Paper CWR 15, Institute for Urban and Regional Studies, Washington University, February 1968), pp, 13,14
}

The apparent relationship between $\mathbf{E}_{g}$ growth and per capita income gains found in the Spearman correlation analysis may reflect both the lack of a completely elastic labor supply and some rigidities in the labor market. In the absence of infinite elasticity in the labor supply, any increase in demand for labor as a result of new employment in export industries tends to raise money wages throughout the labor market. Higher per capita income will result. Even with a relatively elastic labor supply, if the new geographically-oriented employees are paid higher than average wage rates in the community as a result of collective bargaining agreements or other nonmarket factors, average per capita money income in the area will rise.

Some relationship between employment and population growth can be anticipated except in unusual situations. The labor force tends to rise with an increase in population in the absence of unusual distribution of the various age groups.

\section{Growth Related to Education and Skills}

The differences in nominal incomes among SMSAs can be traced to a multiplicity of factors. Sizeable differences in living costs occur between various sections of the nation and among the various cities, according to the United States Department of Agriculture. ${ }^{13}$ Food costs in metropolitan areas are generally higher than in the small cities, while total costs in the Northeast are generally greater than in the rest of the nation. Although the study did not provide direct comparisons between two CMV metropolitan areas, the fact that living costs in St. Louis were 1 per cent above the national average, while Nashville, Tennessee and Baton Rouge, Louisiana were 5 and 6 per cent respectively below the national average, indicates that differences in living costs account for part of the difference in nominal per capita incomes among the CMV metropolitan areas. Part of the nominal income difference, however, surely reflects a difference in well-being.

Variations in real per capita income levels among SMSAs are probably more related to unequal labor and managerial skills than to autonomous growth in a specific industrial sector. Theodore W. Schultz estimated on a tentative basis that the stock of educational capital in the labor force rose about one and one-half times the stock of tangible capital between 1929 and 1957, implying that the growth of invest-

13U.S. Department of Agriculture, The Farm Index (January $1969)$, pp. 19,20 . 
ment in man is a major source of economic growth ${ }^{\text {14 }}$ In a series of regression analyses, Jacob Mincer found that the rate of retum to various types of on-the-job training and to a college education were about equal. ${ }^{15}$

Edward Denison has specified the importance of labor force education:

\begin{abstract}
A better educated work force - from top management down - will be better able to learn about and to utilize the most efficient production practices known. ... Additional education, especially general education, presumably increases versatility, mobility and awareness of employment opportunities. ${ }^{16}$
\end{abstract}

\section{SMSA Employment and Population Affected by Farm Sector}

Part of the difference in employment growth among SMSAs in the CMV may be associated with unequal rates of migration from farm to nonfarm occupations. Rapid growth in farm output per person relative to demand for farm products since the end of World War II has resulted in a major reduction in farm workers and a mass migration from rural to urban type occupations throughout the nation. Although such migration is still sizeable, it has been on the wane in recent years as indicated by the slower rate of arbanization (Table VII).

This moderation in the rate of urbanization is observable in the Central Mississippi Valley. The sharp uptrend in urbanization here occurred somewhat later than in the nation as a whole because of the slower rate of agricultural and industrial development. ${ }^{17}$ Missouri, with 51 per cent of the population living in urban areas, was the most urbanized state in the region in 1930. At the other end of the scale, Mississippi and Arkansas had only 17 and 21 per cent of their respective popu" lations living in urban areas.

\footnotetext{
14"Theodore W. Schult, "Reflections on Investment in Man," Journal of Political Economy, (Supplement: October 1962), pp. $1-8$.

15i5acob Mincer, "On the Job Training: Costs, Returns, and Some Implications," Joumal of Political Economy, (Supplement: October 1962), pp. 50-79.

${ }^{16 E d w a r d ~ F, ~ D e n i s o n, ~ W h y ~ G r o w t h ~ R a t e s ~}$ Differ (Washington: The Brookings Institution, 1967), pp. 79-80.

17The declining rate of urbanization was documented earlier by Clifton B. Luttrell and Claire Amnentrout, "Growth - Metropolitan vs. Nonmetropolitan Areas in the Central Mississippi Valley," this Retiew (January 1969),
}

By 1970 the urban population of Missouri accounted for 63 per cent of the state total, a slightly greater per cent than in the nation. Furthermore, urbanization in Mississippi and Arkansas had moved sharply upward, rising to 39 and 44 per cent respectively.

Although the CMV metropolitan population grew at less than the national rate on a weighted average basis in the 1960-68 period, most areas in the region grew faster than the national average (Table I). Those areas with the lowest growth rates are located in the northern portion of the region, and those with the highest growth rates in the southern portion of the region, reflecting the tardy farm to nonfarm adjustments in the South.

\section{Employment Reflects Both Labor Supply and Demand}

Rapid employment and per capita income growth in most CMV metropolitan areas probably reflects, in addition to rising demand for some local export products, both a more rapid growth in labor supply and an improvement in the quality of the labor force compared with the national average. Employment growth in the region exceeded the average growth rate for large labor market areas in the nation during the 1960-68 period. Eight of the nine SMSAs in the region exceeded the national SMSA average growth rate of 2.6 per cent (Table II). Employment growth in the region was fed by a supply of migrants from rural to urban areas. Since per capita income growth was above the national average despite the increase in number of workers, labor productivity was apparently rising at a relatively high rate.

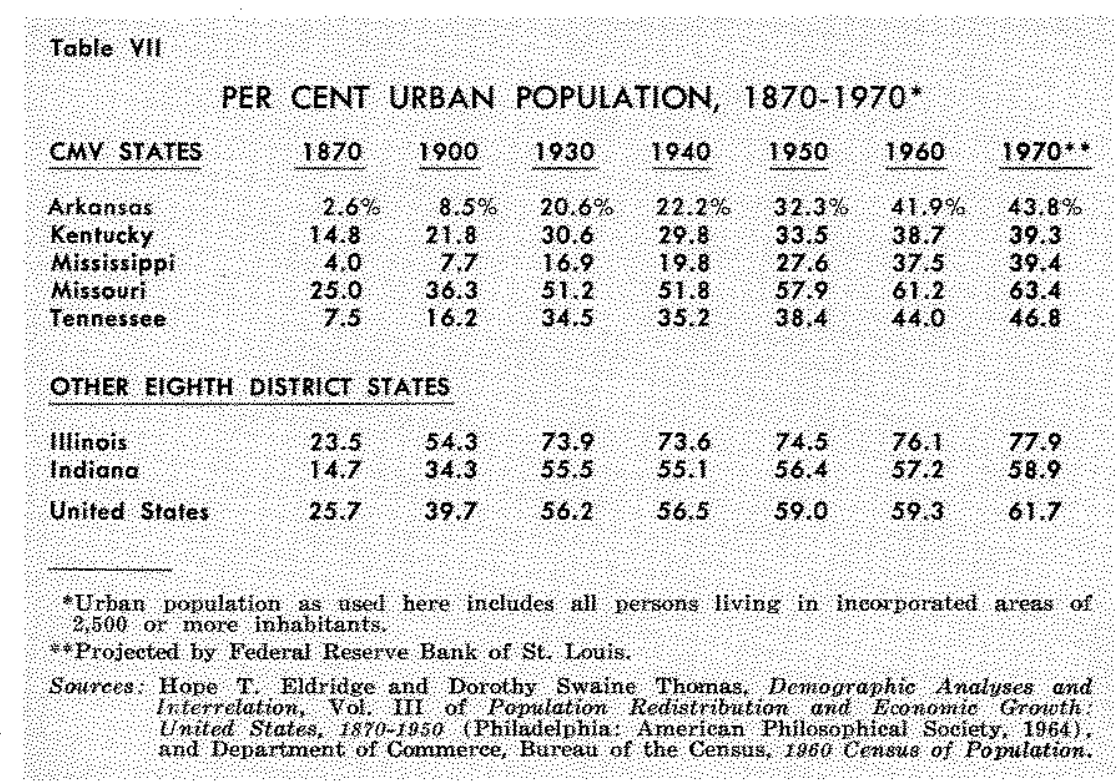


Improved educational programs and labor skills were probably important factors in this high rate of growth in productivity and well-being. Some relative improvement may have occurred in the quality of schools for most people in the area. Military training for the area's youth during and since World War II has likely contributed to regional labor skills. In addition, there has been a wide dissemination of labor skills in the smaller cities and rural areas through more extensive on-the-job contacts with highly skilled people in recent years.

\section{Summary}

Employment growth in Central Mississippi Valley metropolitan areas exceeded the national SMSA average for major labor markets during the 1960-68 period. Population grew at a slightly lower rate and per capita personal income at a slightly higher rate than the national SMSA average.

Wide variations occurred in growth rates among the various SMSAs in the region. Employment growth rates ranged from 2.3 to 4.6 per cent, population from 0.2 to 2.2 per cent, and per capita personal income from 2 to 6.4 per cent.

Regression analysis indicates that growth in the export base sector does not always create multiple employment expansion throughout the local economy. With the exception of perhaps three SMSAs in the CMV, additional workers in local export occupations had only a slight impact on employment in the urban-oriented sector of the local economy. In some instances such service type employment is actually crowded out. Rank correlation analysis of all the SMSAs indicates no significant relationship between export base employment and total employment growth or between export base employment and population growth.

Nevertheless, export base employment growth was apparently an important factor in raising the level of per capita money income in some SMSAs. Rank correlations indicate a significant relationship here, and with nominal per capita gains, some real income gains were probably realized.

This study provides evidence that such supply factors as quantity and quality of labor and managerial skills and availability of capital may have been as important as demand for export base products in determining growth in the $\mathrm{CMV}$ metropolitan areas. The SMSAs located near large reservoirs of lower income farm labor had the more rapid growth rates in employment, population, and per capita personal income. A high rate of growth in farm technology contributed to urbanization in these areas, and more uniform educational programs nationally have undoubtedly narrowed the labor and managerial skill gap between CMV and national SMSAs. As this gap continues to narrow, the differential in productivity will also diminish. The long-run impact of these trends is a gradual reduction of the regional disparities in personal income and well-being.

This article is available as Reprint No. 58 . 